\title{
Asupan Vitamin D Rendah dan Keparahan Demam Berdarah Dengue pada Anak Usia 1-14 Tahun
}

\section{Low Intake of Vitamin D dan Severity of Dengue Hemorrhagic Fever in Children Ages 1-14 Years}

\author{
Nur Siyam*, Siswanto Agus Wilopo**, Mohammad Hakimi**
}

\begin{abstract}
*Departemen Epiodemiologi dan Biostatistik Jurusan Ilmu Kesehatan Masyarakat Fakultas Ilmu Keolahragaan Universitas Negeri Semarang, **Departemen Kesehatan Masyarakat Fakultas Kedokteran Universitas Gadjah Mada
\end{abstract}

\begin{abstract}
Abstrak
Demam berdarah dengue (DBD) menimbulkan syok dan kematian. Penderita DBD di Yogyakarta sebagian besar usia 1 - 12 tahun dengan DBD parah. Asupan vitamin D rendah diasumsikan penyebab DBD parah. Asumsi ini perlu dibuktikan dengan menganalisis pengaruh asupan Vitamin D dan keparahan DBD. Rancangan penelitian adalah studi kasus kontrol. Penelitian di bangsal rawat inap anak dan instalasi catatan medik RS Jogja dan RSUP Dr. Sardjito. Kasus adalah anak usia 1 - 14 tahun dengan DBD grade III \& IV, kontrolnya DBD grade I \& II. Data asupan vitamin D diambil dengan food frequency questionnaire (FFQ). Variabel luar adalah indeks massa tubuh (IMT), usia, status penyakit kronis dan intensitas terpapar matahari pagi. Analisis dengan uji-t dan regresi logistik. Hasil penelitian didapatkan 60 kasus dan 60 kontrol tanpa matching. Cut-off point asupan vitamin D berdasarkan ROC curve adalah 2,7 $\mu \mathrm{g} /$ hari. Penderita DBD parah rata-rata asupan vitamin D 1,10 kali lebih sedikit dibandingkan DBD tidak parah. Rata-rata asupan vitamin D lebih rendah $1 \mu \mathrm{g} /$ day bersama IMT $\geq 18,75 \mathrm{~kg} / \mathrm{m}^{2}$, penyakit kronis, dan kurang terpapar matahari pagi berpengaruh pada DBD parah (OR=0,47; 95\% Cl: 0,32-0,71). Cukup Asupan vitamin $\mathrm{D}$ disarankan untuk menghindari keparahan DBD. Penyakit kronis dan berat badan lebih perlu menjadi perhatian tenaga medis sebagai kewaspadaan dini terjadinya shock.

Kata Kunci: Anak usia 1 - 14 tahun, asupan vitamin D, demam berdarah dengue, tingkat keparahan
\end{abstract}

\section{Abstract}

Dengue hemorrhagic fever (DHF) lead to shock and death. Patient in Yogyakarta mostly aged 1 - 12 years old with severe dengue. A low vitamin $D$ intake is assumed to be the cause of severe dengue. This assumption needs to be proved by analyzing the effect of vitamin D intake and severity of DHF. Study design was a case control study. Research on children's wards and medical record installation in hospital. Cases were children with DHF grade III and IV, the control of DHF grade I \& II. Data vitamin D intake was obtained by FFQ. Outer variables: BMI, age, chronic diseases and intensity morning sun exposure. Analysis by t-test and logistic regression. The results showed 60 cases and 60 controls without matching. Cut-off point vitamin D intake based ROC curve was $2.7 \mu \mathrm{g} /$ day. Patients with severe dengue average vitamin $D$ intake of 1.10 times less than not severe dengue. The average vitamin $D$ intake lower $1 \mu \mathrm{g} /$ day with a $\mathrm{BMI} \geq 18.75 \mathrm{~kg} / \mathrm{m}^{2}$, chronic disease, and less exposed to the morning sun effect on severe dengue $(\mathrm{OR}=0.47,95 \% \mathrm{Cl}: 0.32$ to 0.71$)$. Sufficient vitamin $\mathrm{D}$ intake is recommended to avoid the dengue severity. Chronic diseases and more weight should be a concern of medical personnel as early warning shock occurrence.

Keywords: Children 1 - 14 years old, vitamin D intake, dengue hemorrhagic fever, severity

\section{Pendahuluan}

Penyakit demam berdarah dengue (DBD) merupakan vector-born disease yang potensial menyebabkan kejadian luar biasa (KLB) dan kematian. Sebagian besar penderita DBD pada usia anak dapat mengalami dengue shock syndrome (DSS). Kondisi imunitas anak yang terserang DBD sangat memengaruhi prognosis penyakit tersebut, bisa meningkat menuju DBD yang parah atau sembuh dengan tanpa kegawatan. Vitamin yang dapat digunakan sebagai pengobatan, peningkat daya imunitas tubuh dan pencegahan penyakit infeksi adalah Vitamin D. ${ }^{1}$ Selain dapat berfungsi sebagai antivirus juga dapat berperan sebagai antimicrobial (antibakteri) dalam tubuh. 2,3 Bentuk aktif vitamin D penting untuk meme-

Korespondensi: Nur Siyam, Departemen Epidemiologi dan Biostatistik FIK Universitas Negeri Semarang Gd. F1 Lt. 2 Kampus Sekaran Gunungpati, Semarang 50229, Hp.085642586761, e-mail: nursiyam78@yahoo.com 
ngaruhi sel imun dan dibutuhkan tubuh untuk memproduksi interleukin mediator yang dibutuhkan tubuh dalam melawan virus dengue. ${ }^{4}$ Vitamin D mempunyai fungsi penting dalam menghambat pelepasan pro-inflamatori yang berlebihan, seperti TNF- $\alpha$, INF- $\gamma$, dan IL-12 yang menjadi pemicu disfungsi endotel sehingga menyebabkan kebocoran plasma ${ }^{5}$ sehingga vitamin $\mathrm{D}$ penting untuk mencegah DBD yang lebih parah pada penderitanya.

Para ahli menganjurkan asupan vitamin D 400-800 IU (10-15 $\mu \mathrm{g})$ untuk anak-anak dan remaja didasarkan $10 \mu \mathrm{g}$ vitamin D diharapkan dapat menjamin konsentrasi $25(\mathrm{OH}) \mathrm{D}$ dalam darah $25 \mathrm{nmol} / \mathrm{L}$ atau lebih agar fungsi tubuh dapat berjalan baik. Asupan vitamin D menjadi penting karena walaupun intake vitamin $\mathrm{D}$ juga dapat dihasilkan dari penyinaran matahari pada kulit, tapi sintesisnya di kulit tergantung dari faktor personal (pigmentasi, jaringan cutaneus, usia, dll.), pemakaian tabir surya, jenis pakain penutup badan dan intensitas paparan sinar matahari. ${ }^{6}$ Jadi konsumsi vitamin $\mathrm{D}<10 \mu \mathrm{g} /$ hari dapat menyebabkan kadar vitamin $\mathrm{D}$ di dalam tubuh rendah, sehingga sel-sel imunitas tidak berfungsi baik.

Data dari Kementerian Kelautan dan Perikanan (KKP) tahun 2010, konsumsi ikan di Provinsi DIY memiliki urutan paling bawah secara nasional $(9,74 \mathrm{~kg}$ per kapita per tahun), padahal konsumsi ikan merupakan salah satu sumber asupan vitamin D yang penting. Selain itu, di daerah perkotaan anak-anak lebih banyak menghabiskan waktunya di dalam ruangan. Perubahan gaya hidup masyarakat seiring dengan perkembangan teknologi, menyebabkan anak-anak lebih sering menonton televisi dan bermain game dari telepon genggam, komputer, laptop, dll. Selain itu, pada anak usia sekolah waktu pagi sekitar pukul 07.00-09.00 lebih banyak menghabiskan waktunya di ruang kelas. Sedangkan sebuah penelitian meyebutkan bahwa status serum vitamin $\mathrm{D}$ dalam darah rendah $(<30 \mathrm{ng} / \mathrm{mL})$ meskipun kulit mendapatkan paparan sinar matahari yang berlebih. ${ }^{7}$ Berdasarkan masalah di atas, perlu dilakukan penelitian asupan Vitamin D dan tingkat keparahan DBD pada anak usia 1 - 14 tahun. Penelitian ini bertujuan menganalisis pengaruh asupan vitamin $\mathrm{D}$ terhadap tingkat keparahan DBD pada anak usia 1 - 14 tahun.

\section{Metode}

Jenis penelitian ini observasional analitik dengan rancangan studi kasus kontrol hospital-based. Populasi penelitian ini semua anak usia 1 - 14 tahun yang menderita DBD di Yogyakarta tahun 2013, dirawat/ pernah mendapat perawatan di RSUP Dr. Sardjito dan RS Jogja. Kelompok kasus yaitu anak usia 1 - 14 tahun yang didiagnosis DBD grade III dan IV, dan kelompok kontrol yaitu anak usia 1 - 14 tahun yang didiagnosis DBD grade I dan II pada bulan Maret - Oktober 2013. Penelitian ini telah mendapatkan kelaikan etik dari Komite Etik
Penelitian Biomedis pada manusia Fakultas Kedokteran Universitas Gadjah Mada. Pengumpulan data penelitian di RS Jogja dilakukan bulan Agustus - November 2013, dan di RSUP Dr. Sardjito dilakukan bulan Oktober November 2013.

Pengambilan sampel penelitian menggunakan teknik nonprobability sampling, dengan metode konsekutif sampling. Dalam penelitian, jumlah sampel tidak memenuhi, peneliti mengambil data di bagian rekam medis. Subjek yang diambil dari rekam medis adalah data pasien dari bulan Maret 2013 - Oktober 2013. Setelah itu, dipilih subjek yang memenuhi kriteria dengan data rekam medis yang lengkap, mempunyai nomor telepon/handphone, dan berdomisili di Yogyakarta. Jumlah sampel yang didapatkan selama penelitian adalah 120 subjek.

Variabel bebas adalah asupan vitamin D, variabel terikat tingkat keparahan DBD, dan variabel luar (indeks massa tubuh (IMT), status penyakit kronis, usia dan intensitas terpapar matahari pagi). Instrumen penelitian adalah formulir penelitian dan FFQ. Data yang diambil adalah data umum dan data identitas, antropometri, laboratorium dan intensitas terpapar matahari pagi subjek penelitian. Food Frequency Questionnaire (FFQ) untuk mengumpulkan asupan vitamin D selama satu bulan terakhir yang datanya diambil satu kali pengukuran. Pengukur berat badan dan tinggi badan digunakan timbangan $\mathrm{BB}$ dan pengukur $\mathrm{TB}$ yang ada di rumah sakit tempat penelitian.

Analisis data meliputi data asupan vitamin D yang dianalisis dengan software Nutrisurvey, analisis ROC Curve untuk menentukan cut-off point dari asupan vitamin D dan IMT terhadap keparahan DBB, analisis univariabel, bivariabel, dan multivariabel. Uji statistik antara asupan vitamin D dan keparahan DBD dengan uji-t, untuk analisis variabel luar menggunakan uji-t dan kai kuadrat, ini dilakukan untuk pertimbangan dalam analisis multivariabel. Analisis multivariabel dengan regresi logistik dengan nilai $\mathrm{p}<0,05$ dan confident interval $95 \%$.

Formulir FFQ semikuantitatif ini sudah baku, jenis makanan dari FFQ ini adalah makanan yang dikonsumsi anak usia 1 - 14 tahun di Yogyakarta dan ditambahi bahan makanan yang menurut referensi mengandung vitamin D. Uji coba FFQ dilakukan di Purworejo. Data asupan Vitamin D yang didapatkan dari FFQ ini dapat menggambarkan kecukupan vitamin D pada subjek penelitian dalam pengambilan datanya dilengkapi ukuran khas setiap porsi (ukuran rumah tangga/URT), terdapat kolom ukuran berat (gram). Selain itu, juga digunakan food models untuk membantu responden mengingat dan memperkirakan porsi dan jenis makanan yang dikonsumsi. FFQ dapat digunakan untuk menilai kondisi asupan vitamin $\mathrm{D}$ dengan valid. Hasil penelitian terdahulu menyebutkan bahwa FFQ lebih valid dalam mengukur 
Tabel 1. Distribusi Frekuensi Subjek Penelitian Berdasarkan Kelompok Kasus dan Kontrol

\begin{tabular}{|c|c|c|c|c|c|c|c|}
\hline \multirow{2}{*}{ Variabel } & \multirow{2}{*}{ Kategori } & \multicolumn{4}{|c|}{ Status Subjek } & \multirow{2}{*}{ Total } & \multirow{2}{*}{$\%$} \\
\hline & & Kasus & $\%$ & Kontrol & $\%$ & & \\
\hline \multirow[t]{2}{*}{ Jenis kelamin } & Laki-laki & 26 & 21,7 & 31 & 25,8 & 57 & 47,5 \\
\hline & Perempuan & 34 & 28,3 & 29 & 24,2 & 63 & 52,5 \\
\hline \multirow[t]{2}{*}{ Usia } & $<5$ tahun & 16 & 13,3 & 10 & 8,3 & 26 & 21,7 \\
\hline & $\geq 5$ tahun & 44 & 36,7 & 50 & 41,7 & 94 & 78,3 \\
\hline \multirow[t]{2}{*}{ Asupan vitamin D } & $<2,7 \mu \mathrm{g} / \mathrm{hari}$ & 42 & 35 & 16 & 13,3 & 58 & 48,3 \\
\hline & $\geq 2,7 \mu \mathrm{g} /$ hari & 18 & 15 & 44 & 36,7 & 62 & 51,7 \\
\hline \multirow[t]{2}{*}{ Indeks massa tubuh } & $>18,75 \mathrm{~kg} / \mathrm{m}^{2}$ & 38 & 31,7 & 22 & 19,2 & 61 & 50,0 \\
\hline & $\leq 18,75 \mathrm{~kg} / \mathrm{m}^{2}$ & 22 & 18,3 & 38 & 30,8 & 59 & 50,0 \\
\hline \multirow{2}{*}{ Status penyakit kronis } & Sakit & 26 & 22,5 & 15 & 12,5 & 42 & 35,0 \\
\hline & Tidak sakit & 34 & 27,5 & 45 & 37,5 & 78 & 65,0 \\
\hline \multirow{2}{*}{ Intensitas terpapar matahari pagi } & $<15$ menit & 45 & 37,5 & 34 & 28,3 & 79 & 65,8 \\
\hline & $\geq 15$ menit & 15 & 12,5 & 26 & 21,7 & 41 & 34,2 \\
\hline \multirow{2}{*}{ Pemakaian tabir surya } & Pakai & 16 & 13,3 & 18 & 15,0 & 34 & 28,3 \\
\hline & Tidak pakai & 44 & 36,7 & 42 & 35,0 & 86 & 71,7 \\
\hline \multirow{2}{*}{ Pemakaian jenis pakaian } & Panjang/tertutup & 44 & 36,7 & 36 & 30,0 & 80 & 66 \\
\hline & Pendek/terbuka & 16 & 13,3 & 24 & 20,0 & 40 & 33,3 \\
\hline \multirow[t]{2}{*}{ Jumlah hari perawatan } & $>5$ hari & 22 & 18,3 & 13 & 10,8 & 35 & 29,2 \\
\hline & $\leq 5$ hari & 38 & 31,7 & 47 & 39,2 & 85 & 70,8 \\
\hline
\end{tabular}

asupan kalsium dan vitamin D pada anak perempuan remaja dengan anoreksia nervosa dan remaja sehat dibandingkan food record sehingga FFQ dapat dijadikan rekomendasi sebagai alat screening pada penelitian klinis. ${ }^{8}$

Sumber vitamin D yang didapatkan melalui asupan dan suplemen penting dinilai untuk memperkirakan ketersediaan vitamin D dalam tubuh. ${ }^{9}$ Pengukuran kadar vitamin D di dalam darah pasien DBD secara langsung tidak dilakukan karena memerlukan biaya yang relatif mahal dan kurang tepat bila diterapkan di komunitas.

\section{Hasil}

Penelitian dilakukan pada 120 subjek penderita DBD berusia 1-14 tahun yang dirawat di RS Jogja dan di RSUP DR. Sardjito, yang terdiri dari 60 kasus dan 60 kontrol (tanpa matching 1:1). Karakteristik subjek penelitian terlihat pada Tabel 1.

Analisis ROC curve dilakukan untuk menentukan batas nilai (cut-off point) toleransi dalam uji diagnostik antara asupan vitamin D dengan keparahan DBD (Gambar 1). Gambar 1 cut-off point terletak pada nilai sensitivitas $=73,33 \%$ dan nilai 1 -spesifisitas $=70,00 \%$. Hasil analisis ROC curve, pada titik potong ini menunjukkan nilai asupan vitamin $\mathrm{D}=2,7 \mu \mathrm{g} / \mathrm{hari}$. Nilai sensitivitas ini menunjukkan probabilitas subjek yang mempunyai asupan vitamin $\mathrm{D}<2,7 \mu \mathrm{g} /$ hari akan didiagnosis mengalami DBD yang parah sebesar $73,33 \%$. Nilai spesifisitas menunjukkan probabilitas subjek yang mempunyai asupan vitamin $\mathrm{D}<2,7 \mu \mathrm{g} /$ hari akan didiagnosis mengalami DBD yang tidak parah sebesar 30,0\%. Selain itu, nilai titik potong ini dipilih dengan pertimbangan positive predictive value (PPV) dan negative predictive value (NPV) yang seimbang dan yang paling tinggi

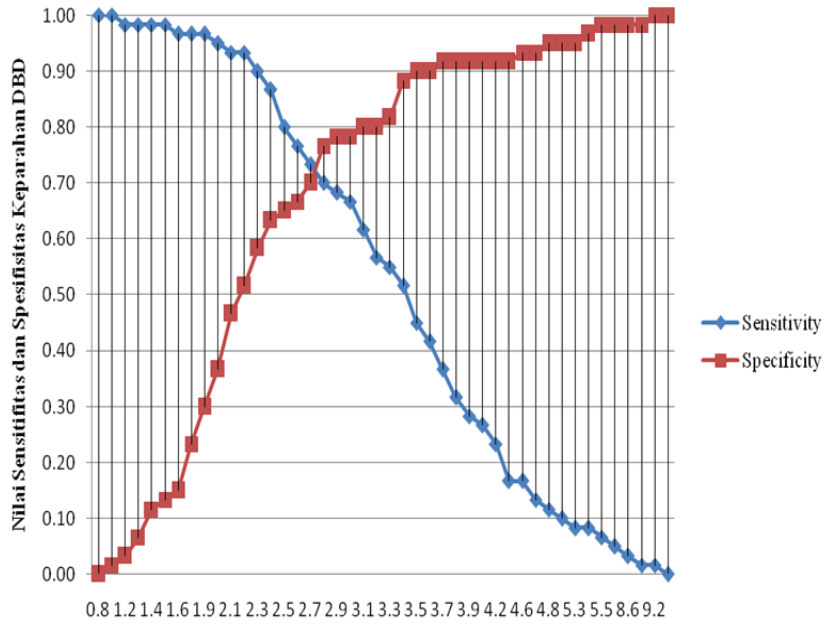

Cut of Point Asupan Vitamin D ( $\mu \mathrm{g} / \mathrm{hari})$

Gambar 1. Nilai Cut-off Point Sensitivitas dan Spesifisitas Keparahan DBD Berdasarkan Asupan Vitamin D

(mendekati 100\%). Ini artinya, proporsi subjek yang diklasifikasikan sebagai DBD yang parah akan benar-benar mengalami DBD yang parah sebesar $72,42 \%$. Jadi dapat ditentukan nilai batasan asupan vitamin $\mathrm{D}$ adalah $\geq 2,7$ $\mu \mathrm{g} /$ hari untuk menghindari keparahan DBD.

Gambar 2, cut-off point terletak pada nilai sensitivitas $=63,33 \%$ dan nilai 1 -spesifisitas $=63,33 \%$. Hasil analisis ROC curve, pada titik potong ini menunjukkan nilai IMT $=18,75 \mathrm{~kg} / \mathrm{m}^{2}$. Nilai sensitivitas ini menunjukkan probabilitas subjek yang mempunyai IMT $\geq 18,75 \mathrm{~kg} / \mathrm{m}^{2}$ akan didiagnosis mengalami DBD yang parah sebesar $63,33 \%$. Jadi dapat ditentukan nilai batasan IMT $<18,75$ $\mathrm{kg} / \mathrm{m}^{2}$ untuk dapat menghindari keparahan DBD.

Analisis antara asupan vitamin D dengan tingkat keparahan DBD (Tabel 2), menunjukkan ada pengaruh 
yang bermakna antara asupan vitamin $\mathrm{D}$ anak dengan tingkat keparahan DBD (nilai $\mathrm{p}=0,000, \Delta$ mean $=-1,10$, CI $(95 \%)$ : -1,59-(-0,62)). Dengan demikian, dapat dikatakan bahwa ada perbedaan rata-rata asupan vitamin D pada kelompok DBD yang parah dengan yang tidak parah sebesar 1,10. Pada penderita DBD yang parah mempunyai rata-rata asupan vitamin D sebesar 1,10 kali lebih sedikit dibandingkan pada DBD yang tidak parah.

Analisis antara status penyakit kronis, IMT, usia, dan intensitas terpapar matahari pagi dengan asupan vitamin $\mathrm{D}$ dengan kai kuadrat, menunjukkan tidak ada pengaruh yang bermakna status penyakit kronis anak dengan asupan vitamin $\mathrm{D}(\mathrm{OR}=1,38$, CI $(95 \%) 0,61-3,16)$. IMT berkontribusi terhadap asupan vitamin $\mathrm{D}$ pada anak usia 1 - 14 tahun $(\mathrm{OR}=2,25$, CI $(95 \%)$ 1,02-4,99). Ada pengaruh yang bermakna antara usia anak dengan tingkat

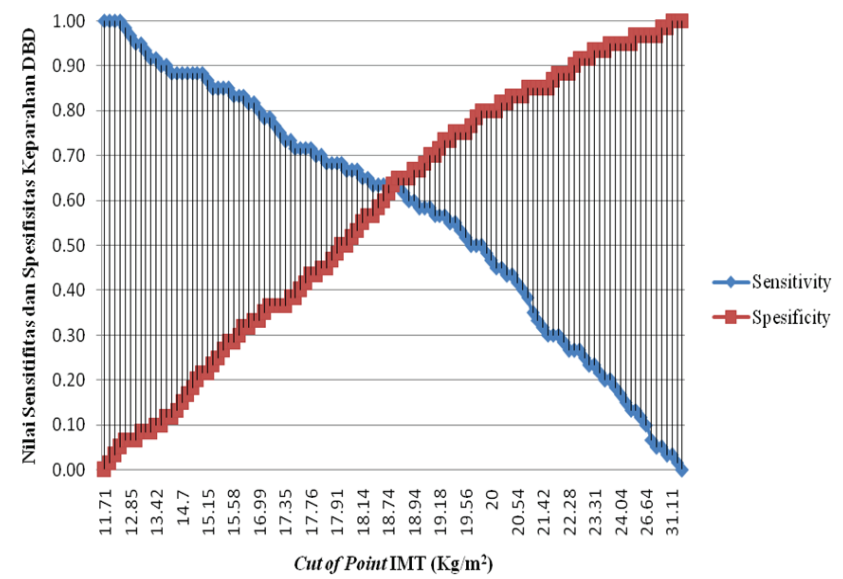

Gambar 2. Grafik Nilai Cut-off Point Sensitifitas dan Spesifisitas Keparahan DBD Berdasarkan IMT asupan vitamin D, artinya usia anak memberikan kontribusi terhadap asupan vitamin D pada anak usia $1-14$ tahun, dilihat dari hasil analisis $(\mathrm{OR}=0,31$, CI $(95 \%)$ $0,10-0,87)$. Sedangkan hasil analisis uji-t menunjukkan hasil yang berbeda dengan uji kai kuadrat, semua variabel luar tidak menunjukkan nilai yang signifikan $(p>0,05)$.

Analisis antara status penyakit kronis, IMT, usia, dan intensitas terpapar matahari pagi dengan keparahan DBD (Tabel 3), menunjukkan ada pengaruh yang bermakna antara IMT dengan keparahan DBD $(\mathrm{OR}=2,78$, CI $(95 \%) 1,25-6,23)$. Tidak terdapat pengaruh yang bermakna antara usia anak dengan tingkat keparahan DBD $(\mathrm{OR}=1,82$, CI $(95 \%)$ 0,69-4,96). Terdapat pengaruh status penyakit kronis anak dengan tingkat keparahan DBD (OR=2,29, CI (95\%) 1,06-4,96). Anak dengan DBD yang parah ditemukan lebih besar 2,29 kali pada mereka yang mempunyai sakit kronis dibandingkan pada anak dengan DBD tidak parah. Terdapat pengaruh yang bermakna antara intensitas terpapar matahari dengan tingkat keparahan DBD (OR=2,29, CI $(95 \%) 1,06$ $4,96)$. Anak dengan DBD yang parah ditemukan lebih besar 2,29 kali pada mereka yang mempunyai intensitas terpapar matahari pagi $\geq 15$ menit/hari dibandingkan pada anak dengan DBD tidak parah.

Peneliti melakukan analisis multivariabel, didapatkan empat model (Tabel 4). Penulis memilih Model 2 sebagai model yang secara statistik dan praktis menggambarkan pengaruh asupan vitamin D dengan keparahan DBD yang dikontrol variabel luar (IMT, status penyakit kronis dan intensitas terpapar matahari pagi). Model ini menunjukkan bahwa pengaruh asupan vitamin D dengan keparahan DBD memiliki OR yang paling tinggi dari ke tiga model lainnya $(\mathrm{OR}=0,47,95 \% \mathrm{CI}: 0,32-0,71)$,

Tabel 2. Hasil Analisis Uji-T Asupan Vitamin D dan Tingkat Keparahan Demam Berdarah

\begin{tabular}{|c|c|c|c|c|c|c|c|c|}
\hline \multirow{2}{*}{ Variabel } & \multicolumn{2}{|c|}{ Parah } & \multicolumn{2}{|c|}{ Tidak Parah } & \multirow{2}{*}{$\Delta$ mean } & \multirow{2}{*}{$T$} & \multirow{2}{*}{ nilai p } & \multirow{2}{*}{ 95\% CI } \\
\hline & Mean & $\pm \mathrm{SD}$ & Mean & $\pm \mathrm{SD}$ & & & & \\
\hline Asupan vitamin $\mathrm{D}(\mu \mathrm{g} / \mathrm{hr})$ & 2,44 & 1,27 & 3,53 & 1,42 & $-1,10$ & $-4,49$ & 0,0000 & $-1,59-(-0,62)$ \\
\hline
\end{tabular}

Tabel 3. Hasil Analisis Tes Kai Kuadrat antara Status Penyakit Kronis, IMT, Usia, dan Intensitas Terpapar Matahari Pagi terhadap Tingkat Keparahan DBD

\begin{tabular}{|c|c|c|c|c|c|c|c|c|c|}
\hline \multirow{2}{*}{ Variabel } & \multirow{2}{*}{ Kategori } & \multicolumn{4}{|c|}{ Tingkat Keparahan DBD } & \multirow{2}{*}{$x^{2}$} & \multirow{2}{*}{ nilai $p$} & \multirow{2}{*}{ OR } & \multirow{2}{*}{ 95\% CI } \\
\hline & & Parah & $\%$ & Tidak parah & $\%$ & & & & \\
\hline \multirow[t]{2}{*}{ Indeks massa tubuh } & $>18,75 \mathrm{~kg} / \mathrm{m}^{2}$ & 38 & 63,3 & 23 & 38,3 & \multirow[t]{2}{*}{7,50} & \multirow[t]{2}{*}{$0,003^{* * *}$} & \multirow[t]{2}{*}{2,78} & \multirow[t]{2}{*}{$1,25-6,23$} \\
\hline & $\leq 18,75 \mathrm{~kg} / \mathrm{m}^{2}$ & 22 & 36,7 & 37 & 61,7 & & & & \\
\hline \multirow[t]{2}{*}{ Usia } & $<5$ tahun & 16 & 26,7 & 10 & 16,7 & \multirow[t]{2}{*}{1,77} & \multirow[t]{2}{*}{0,184} & \multirow[t]{2}{*}{1,82} & \multirow[t]{2}{*}{$0,69-4,96$} \\
\hline & $\geq 5$ tahun & 44 & 73,3 & 50 & 83,3 & & & & \\
\hline \multirow[t]{2}{*}{ Status penyakit kronis } & Sakit & 26 & 43,3 & 15 & 15,0 & \multirow[t]{2}{*}{4,48} & \multirow[t]{2}{*}{$0,0342 *$} & \multirow[t]{2}{*}{2,29} & \multirow[t]{2}{*}{$1,06-4,96$} \\
\hline & Tidak sakit & 34 & 56,7 & 45 & 75,0 & & & & \\
\hline \multirow{2}{*}{$\begin{array}{l}\text { Intensitas terpapar } \\
\text { matahari pagi }\end{array}$} & $<15$ menit/hari & 45 & 75,0 & 34 & 56,7 & \multirow[t]{2}{*}{4,48} & \multirow[t]{2}{*}{$0,0342 *$} & \multirow[t]{2}{*}{2,29} & \multirow[t]{2}{*}{$1,06-4,96$} \\
\hline & $\geq 15$ menit/hari & 15 & 15,0 & 26 & 43,3 & & & & \\
\hline
\end{tabular}

Keterangan: *signifikan nilai $\mathrm{p}<0,05 ; * *$ signifikan nilai $\mathrm{p}<0,01 ; x^{2}=$ kai kuadrat; $\mathrm{OR}=$ Odds Ratio 
Siyam, Wilopo, Hakimi, Asupan Vitamin D Rendah Meningkatkan Keparahan DBD

Tabel 4. Hasil Analisis Regresi Logistik antara Asupan Vitamin D dan Tingkat Keparahan DBD) dengan Mengikutsertakan Variabel Luar

\begin{tabular}{|c|c|c|c|c|c|}
\hline \multirow{2}{*}{ Variabel } & \multirow{2}{*}{ Kategori } & \multicolumn{4}{|c|}{ Model Regresi Logistik } \\
\hline & & $\begin{array}{c}\text { Model } 1 \\
\text { OR(95\% CI) }\end{array}$ & $\begin{array}{c}\text { Model } 2 \\
\text { OR(95\% CI) }\end{array}$ & $\begin{array}{c}\text { Model } 3 \\
\text { OR(95\% CI) }\end{array}$ & $\begin{array}{c}\text { Model } 4 \\
\text { OR(95\% CI) }\end{array}$ \\
\hline Asupan vitamin D ( $\mu \mathrm{g} /$ hari) & & $0,46(0,30-0,68)^{* * * * *}$ & $0,47(0,32-0,71)^{* * * *}$ & $0,39(0,25-0,60)^{* * * * *}$ & $0,41(0,27-0,64)^{* * * * x}$ \\
\hline Indeks massa tubuh & $\begin{array}{l}\geq 18,75 \mathrm{~kg} / \mathrm{m}^{2} \\
<18,75 \mathrm{~kg} / \mathrm{m}^{2}\end{array}$ & & $2,48(1,06-5,77)^{*}$ & & $2,20(0,92-5,25)$ \\
\hline Status penyakit kronis & $\begin{array}{l}\text { Sakit } \\
\text { Tidak sakit }\end{array}$ & & $3,23(1,26-8,28)^{*}$ & $2,62(1,01-6,79)^{*}$ & $2,77(1,05-7,29)^{*}$ \\
\hline Umur & $\begin{array}{l}<5 \text { tahun } \\
\geq 5 \text { tahun }\end{array}$ & & & $3,99(1,24-12,90)^{*}$ & $3,48(1,06-11,35)^{*}$ \\
\hline Intensitas terpapar matahari pagi & $\begin{array}{l}<15 \mathrm{menit} / \text { hari } \\
\geq 15 \mathrm{menit} / \text { hari }\end{array}$ & & $2,79(1,12-6,94)^{*}$ & $2,94(1,17-7,34)^{*}$ & $2,84(1,11-7,24)^{*}$ \\
\hline $\mathrm{N}$ & & 120 & 120 & 120 & 120 \\
\hline Log likelihood & & $-72,43$ & $-64,67$ & $-63,77$ & $-62,17$ \\
\hline$x^{2}$ hitung & & 21,49 & 37,36 & 38,82 & 42,01 \\
\hline $\mathrm{R}^{2}$ & & 0,13 & 0,23 & 0,23 & 0,25 \\
\hline
\end{tabular}

Keterangan: *signifikan nilai $\mathrm{p}<0,05,{ }^{* *}$ signifikan nilai $\mathrm{p}<0,01$, ****signifikan nilai $\mathrm{p}<0,001, \mathrm{R}^{2}=$ Koefisien determinasi, OR= Odds Ratio, CI= Confidence Interval

artinya pada anak yang mempunyai asupan vitamin D lebih tinggi $1 \mu \mathrm{g} /$ hari akan menurunkan risiko terjadinya DBD yang parah sebesar $54 \%$, bila anak tersebut juga mempunyai IMT $<18,75 \mathrm{~kg} / \mathrm{m}^{2}$, tidak mempunyai penyakit kronis, dan mempunyai intensitas terpapar matahari pagi $\geq 15 \mathrm{mnt} / \mathrm{hr}$. Selain itu, Model 2 memiliki nilai koefisien determinasi $\left(\mathrm{R}^{2}\right)$ yang relatif tinggi dan nilai $\log$ likelihood dan $x^{2}$ hitung yang tidak jauh berbeda dengan model 3 dan 4. Artinya, Model 2 ini mempunyai residu yang lebih rendah dari pada Model 1 dan relatif sama dengan Model 3 dan 4.

Hasil analisis Model 2, variabel IMT, status penyakit kronis dan intensitas terpapar matahari pagi menunjukkan pengaruh yang bermakna. Usia tidak disertakan dalam model ini karena dalam analisis bivariat variabel usia tidak berpengaruh terhadap keparahan DBD. Model 2 ini dapat memprediksi keparahan DBD sebesar $23 \%$ yang ditunjukkan dengan nilai $\mathrm{R}^{2}=0,23$ dan nilai OR yang bermakna secara praktis maupun statistik.

\section{Pembahasan}

\section{Asupan Vitamin D dan Keparahan DBD}

Hasil analisis bivariabel (Tabel 2) dan multivariabel (Tabel 4) menunjukkan bahwa secara statistik ada pengaruh antara asupan vitamin D dengan tingkat keparahan DBD. Asupan vitamin D merupakan variabel yang paling dominan dari variabel yang lain. Berdasarkan hasil analisis, asupan vitamin D menunjukkan signifikansi yang tetap stabil. Dapat disimpulkan bahwa asupan vitamin D memberikan kontribusi yang paling besar terhadap keparahan DBD pada anak usia 1 - 14 tahun.
Proses biokimia yang dilakukan 1,25 $(\mathrm{OH})_{2}$ vitamin D3 1,25 $(\mathrm{OH})_{2}$ vitamin D3 umumnya mengaktifkan respons imun bawaan dengan peningkatan diferensiasi makrofag dan fagositosis dan produksi lebih besar dari peptida antimikroba yang dapat meningkatkan membunuh mikroba. ${ }^{10}$ Dalam jaringan dan kelenjar getah bening, 1,25 $(\mathrm{OH})_{2}$ vitamin D3 menghambat respon imun adaptif, terutama dengan menghalangi pematangan sel dendritik myeloid dengan mengurangi ekspresi molekul ko-stimulator, menghambat sekresi IL-12, dan meningkatkan produksi IL-10. 1,25 $(\mathrm{OH})_{2}$ vitamin D3 juga memiliki efek langsung pada sel $\mathrm{T}$, yaitu menyebabkan penurunan sekresi IFN- $\gamma$ oleh sel T helper 1 (Th1) dan merangsang perkembangan sel Th2 dengan peningkatan produksi IL-4, IL-5, dan IL-10.4

Konsentrasi TNF- $\alpha$ berhubungan dengan kerentanan penyakit DBD. ${ }^{5}$ Kecenderungan genetik yang menyebabkan tingginya produksi TNF- $\alpha$ dan rendahnya produksi IL-10 meningkatkan kerentanan terhadap infeksi sekunder DENV-2, sebagai serotipe yang paling virulen. Level plasma cytokine, yakni TNF- $\alpha$ dan interleukin (IL), secara signifikan lebih tinggi pada penderita DBD jika dibandingkan dengan penderita DD, dan lebih tinggi juga pada penderita DSS jika dibandingkan dengan penderita DBD. 9

Adanya TNF- $\alpha$ dan IFN- $\gamma$ yang berlebihan akan menyebabkan banyak sel yang terinfeksi diserang oleh antibodi karena dianggap sebagai antigen. Terhambatnya produksi interferon tipe II (IFN- $\gamma$ ) dan TNF- $\alpha$ yang berlebihan dalam tubuh penderita DBD oleh kerena peran $1,25(\mathrm{OH})_{2} \mathrm{D} 3$ akan mengurangi tingkat keparahan DBD. 5 


\section{Status Penyakit Kronis dan Keparahan DBD melalui Status Vitamin D}

Vitamin D meningkatkan kemampuan regulasi sel kekebalan bawaan dan adaptif yang berhubungan langsung atau tidak langsung dalam mengontrol dampak asma. Kecukupan vitamin D dapat mengurangi dua faktor risiko terbesar untuk asma, yaitu sensitisasi atopik dan infeksi awal saluran pernapasan bagian bawah oleh stimulasi produksi peptida antimikroba. ${ }^{11}$ Serum 25 $(\mathrm{OH})$ vitamin $\mathrm{D} 3$ yang lebih tinggi secara signifikan mengurangi risiko diabetes pada anak-anak dan orang dewasa. ${ }^{12}$

Hasil penelitian Figueiredo, et al., ${ }^{13}$ menunjukkan bahwa orang yang memiliki alergi (dan menggunakan steroid) atau mempunyai penyakit diabetes, mempunyai 2,5 kali lebih mungkin untuk memiliki DBD (setelah terpapar DD). Penggunaan steroid meningkatkan risiko DBD yang lebih parah karena dapat menghasilkan kerapuhan kapiler. Pada penderita DM Tipe II, terjadi pelepasan pro-inflamasi sitokin seperti interferon gamma (IFN- $\gamma$ dan TNF) yang berlebihan. Sitokin ini diketahui memiliki peran mendasar dalam salah satu fenomena utama yang bertanggung jawab untuk manifestasi klinis DBD, pergeseran cairan ruang ketiga, yang merupakan konsekuensi dari disfungsi endotel dan menghasilkan hemokonsentrasi, hipotensi dan shock. ${ }^{14}$

\section{IMT dan Tingkat Keparahan DBD}

Berdasarkan hasil analisis multivariabel, semakin tinggi IMT nya, semakin tinggi tingkat keparahan DBD yang dialami anak. Jadi, dapat disimpulkan bahwa IMT memberikan kontribusi terhadap keparahan DBD pada anak. Hal ini sejalan dengan penelitian Kalayanarooj et al. ${ }^{15}$

Indeks massa tubuh seseorang dipengaruhi oleh faktor metabolisme tubuh. Jaringan adiposa memproduksi dan mensekresikan molekul-molekul bioaktif yang bervariasi, yang disebut adipocytokine, termasuk adiponectin, TNF- $\alpha$ (tumour necrosis factor- $\alpha$ ), leptin, dan resistin. ${ }^{16}$ Level plasma adiponectin berhubungan dengan IMT terutama pada orang yang obesitas. Semakin meningkat IMT nya, semakin rendah level adiponectin dalam tubuh. ${ }^{17,18}$ Level adiponektin yang lebih tinggi berhubungan erat dengan level TNF- $\alpha$ yang lebih rendah. ${ }^{19}$ Kebanyakan kasus DBD yang parah terjadi pada anak-anak yang memiliki IMT lebih tinggi/ obesitas. Selain karena faktor autoimun, anak yang obesitas memiliki konsentrasi adiponektin yang lebih rendah sehingga mengakibatkan komplikasi pada kardiovaskular. ${ }^{14,15}$

Berkaitan dengan pengaruh IMT dan tingkat keparahan DBD, seseorang dengan IMT lebih besar mempunyai kadar vitamin D (serum 2,5(OH)D) dalam darah yang lebih rendah. Setiap kenaikan BB $1 \mathrm{~kg}$, menyebabkan penurunan level vitamin $\mathrm{D}$ di dalam darah sebesar 1,3
nmol/L. ${ }^{20}$ Vitamin D dan adiponectin menjadi faktor risiko kardiometabolik pada anak dan remaja yang obes. ${ }^{21}$ Vitamin D memengaruhi regulasi adiponektin. Jika kadar vitamin D di dalam tubuh rendah, kadar adiponektin di dalam tubuh juga rendah. ${ }^{22}$

\section{Intensitas Terpapar Matahari Pagi dan Tingkat Keparahan DBD}

Sesuai dengan hasil analisis bivariabel dan multivariabel, intensitas terpapar matahari pagi yang kurang meningkatkan keparahan DBD. Intensitas terpapar matahari pagi dapat meningkatkan kadar vitamin $\mathrm{D}$ di dalam tubuh. Sinar UVB dapat meningkatkan kekebalan tubuh dan menjadi antivirus dan antimicrobial alami. ${ }^{2,3}$ Selain adanya fungsi vitamin D yang penting dalam menghambat pelepasan pro-inflamatori yang berlebihan yang menjadi pemicu disfungsi endotel, sebagai pemicu kebocoran plasma, intensitas terpapar matahari pagi ini juga penting jika dikaitkan dengan faktor lingkungan yang berhubungan dengan vektor DBD. Perilaku vektor DBD yang lebih suka menggigit di pagi hari, dan mempunyai habitat di dalam ruangan, sangat menguntungkan bagi anak yang aktivitas paginya berada di luar ruangan untuk mendapatkan vitamin $\mathrm{D}$ dan menghindari gigitan nyamuk.

Berdasarkan pembahasan dapat disimpulkan bahwa asupan vitamin D yang rendah, IMT yang tinggi, penyakit kronis, dan kurangnya intensitas terpapar matahari pagi dapat menjadi prediktor dalam meningkatkan keparahan DBD.

\section{Kesimpulan}

Penderita DBD yang parah mempunyai rata-rata asupan vitamin D 1,10 kali lebih sedikit dibandingkan pada penderita DBD yang tidak parah, sedangkan anak yang mempunyai asupan vitamin D lebih tinggi akan menurunkan risiko terjadinya DBD yang parah, bila anak tersebut juga mempunyai IMT $<18,75 \mathrm{~kg} / \mathrm{m}^{2}$, tidak mempunyai penyakit kronis, dan mempunyai intensitas terpapar matahari pagi $\geq 15$ menit per hari. Artinya, penyakit kronis, indeks massa tubuh yang lebih dan intensitas terpapar matahari pagi kurang dari 15 menit per hari lebih banyak ditemukan pada anak yang mempunyai DBD yang parah.

\section{Saran}

Asupan vitamin D dan pemaparan sinar matahari pagi yang cukup disarankan untuk menghindari keparahan DBD pada anak. Selain itu, penyakit kronis dan berat badan lebih (obesitas) perlu menjadi perhatian tenaga medis di RSUP Dr. Sardjito dan RS Jogja sebagai tanda bahaya terhadap kemungkinan syok pada DBD. Instrumen penelitian ini yang telah diuji validitas dan reliabilitasnya dapat digunakan untuk menjaring data asupan vitamin D pasien DBD sehingga deteksi dini terhadap 
DBD yang parah dapat diwaspadai dengan segera untuk penanganan dengan tepat dan cepat.

\section{Ucapan Terima Kasih}

Peneliti mengucapkan terima kasih kepada BPKLN Kementerian Pendidikan dan Kebudayaan sebagai pemberi Beasiswa Unggulan serta RSUP Dr. Sardjito dan RS Jogja atas izin dan kerja sama yang baik dalam penelitian ini.

\section{Daftar Pustaka}

1. Yamshchikov AV, Desai NS, Blumberg HM, Ziegler TR, Tangpricha V. Vitamin D for treatment and prevention of infectious diseases: a systematic review of randomized controlled trials. Endocrine Practice. 2009; 15 (5): 438-49.

2. Youssef DA, Miller CW, El-Abbassi AM, Cutchins DC, Cutchins C, Grant WB, et al. Antimicrobial implications of vitamin D. Dermatoendocrinol. 2011; 3(4): 220-9.

3. Beard JA, Bearden A, Striker R. Vitamin D and the anti-viral state. Journal of Clinical Virology. 2011; 50 (3):194-200.

4. Van Belle TL, Gysemans C, Mathieu C. Vitamin D in autoimmune, infectious and allergic diseases: a vital player? Best Practice \& Research Clinical Endocrinology \& Metabolism. 2011; 25(4): 617-32.

5. Nguyen TH, Lei HY, Nguyen TL, Lin YS, Huang KJ, Le BL, et al. Dengue hemorrhagic fever in infants: a study of clinical and cytokine profiles. The Journal of Infectious Diseases. 2004; 189 (2): 221-32. Epub 2004/01/15.

6. McCarty CA. Sunlight exposure assessment: can we accurately assess vitamin D exposure from sunlight questionnaires? American Journal of Clinical Nutrition. 2008; 87(suppl): 1097S-101S.

7. Binkley N, Novotny R, Krueger D, Kawahara T, Daida YG, Lensmeyer $\mathrm{G}$, et al. Low vitamin D status despite abundant sun exposure. The Journal of Clinical Endocrinology \& Metabolism. 2007; 92 (6):2130 -5.

8. Taylor C, Lamparello B, Kruczek K, Anderson EJ, Hubbard J, Misra M. Validation of a food frequency questionnaire for determining calcium and vitamin D intake by adolescent girls with anorexia nervosa. Journal of the American Dietetic Association. 2009; 109 (3): 479-85, 85 e1-3.

9. Perez AB, Sierra B, Garcia G, Aguirre E, Babel N, Alvarez M, et al. Tumor necrosis factor-alpha, transforming growth factor-beta 1 , and interleukin-10 gene polymorphisms: implication in protection or susceptibility to dengue hemorrhagic fever. Human Immunology. 2010; 71(11): 1135-40
10. Hart PH. Vitamin D supplementation, moderate sun exposure, and control of immune diseases. Immunology. 2012; 73.

11. Paul G, Brehm JM, Alcorn JF, Holguı 'n F, Aujla SJ, Celedó n JC. Vitamin $\mathrm{D}$ and asthma. American Journal of Respiratory and Critical Care Medicine. 2012; 185.

12. Valdivielso JM, Fernandez E. Vitamin D receptor polymorphisms and diseases. Clinica Chimica Acta. 2006; 371(1-2):1-12.

13. Figueiredo MA, Rodrigues LC, Barreto ML, Lima JW, Costa MC, Morato $\mathrm{V}$, et al. Allergies and diabetes as risk factors for dengue hemorrhagic fever: results of a case control study. PLoS Negleted Tropical Disease. 2010; 4(6): e699.

14. Stephenson JR. Understanding dengue pathogenesis: implications for vaccine design. Bulletin of the World Health Organization. 2005; 83(4): 308-14.

15. Kalayanarooj S, Nimmannitya S. Is dengue severity related to nutritional status? The Southeast Asian Journal of Tropical Medicine and Public Health. 2005;36(2):378-84.

16. Matsuda M, Shimomura I, Sata M, Arita Y, Nishida M, Maeda N, et al. Role of adiponectin in preventing vascular stenosis. The missing link of adipo-vascular axis. The Journal of Biological Chemistry. 2002; 277(40): 37487-91.

17. Cohen SS, Gammon MD, Signorello LB, North KE, Lange EM, Fowke $\mathrm{JH}$, et al. Serum adiponectin in relation to body mass index and other correlates in black and white women. Annual of Epidemiology. 2011; 21(2): 86-94.

18. Guerre-Millo M. Adiponectin: an update. Diabetes \& metabolism. 2008;34 (1): 12-8.

19. Wagner A, Simon C, Oujaa M, Platat C, Schweitzer B, Arveiler D. Adiponectin is associated with lipid profile and insulin sensitivity in French adolescents. Diabetes \& metabolism. 2008;34(5):465-71. Epub 2008/08/08.

20. Stein EM, Strain G, Sinha N, Ortiz D, Pomp A, Dakin G, et al. Vitamin $\mathrm{D}$ insufficiency prior to bariatric surgery: risk factors and a pilot treatment study. Clin Endocrinol. 2009;August ; 71(2):176-83.

21. Kardas F, Kendirci M, Kurtoglu S. Cardiometabolic risk factors related to vitamin $\mathrm{D}$ and adiponectin in obese children and adolescents. International Journal of Endocrinology. 2013; 2013: 1-5.

22. Wang CCL, Pereira RI, Hosokawa P, Dickinson LM, Krantz MJ, Neumar C, et al. Association between 25-hydroxyvitamin D and adiponection levels in hypertensive subjects [online]. North Beauregard Street Alexandria; 2010 [ cited 2013 Dec 29]; Available from: http://professional.diabetes.org/Abstracts_Display.aspx?TYP=1\&CID=79769. 